\title{
PENGARUH PENGGUNAAN MULTIMEDIA PEMBELAJARAN DAN GAYA BERPIKIR TERHADAP HASIL BELAJAR BAHASA INGGRIS SISWA MTs. SWASTA DARUL MURSYID TAPANULI SELATAN
}

\author{
Husnil Walad \\ Guru MTs Swasta Darul Mursyid, Sumatera Utara \\ husnil.walad77@gmail.com
}

\begin{abstract}
Abstrak: Penelitian ini merupakan penelitian kuasi eksperimen. Populasi dalam penelitian ini adalah seluruh siswa kelas VIII MTs Swasta Darul Mursyid. Pemilihan sampel dilakukan secara random. Instrumen yang digunakan terdiri dari: (1) tes hasil belajar yang digunakan dalam penelitian ini berbentuk pilihan berganda sebanyak 37 butir soal (2) lembar gaya berpikir belajar siswa sebanyak 15 item. Instrumen tersebut telah memenuhi syarat validitas isi dan validitas konstruk serta koefisien reliabilitas. Data dalam penelitian ini dianalisis dengan menggunakan analisis statistik deskriptif dan analisis inferensial. Analisis inferensial data dilakukan dengan uji Anava $2 x 2$ sampel independen. Hasil penelitian menunjukkan bahwa: (1) dari hasil perhitungan yang diperoleh yang dapat dilihat dari hasil penelitian diperoleh bahwa rara-rata hasil belajar siswa yang diajarkan dengan menggunakan Pembelajaran Multimedia Macromedia Flash adalah 26.36, sedangkan rata-rata hasil belajar siswa yang diajarkan dengan menggunakan pembelajaran multimedia PowerPoint 22.5, sehingga Ho ditolak dan Ha diterima, (2) perhitungan yang diperoleh yang dapat dilihat dari hasil penelitian diperoleh bahwa rata-rata hasil belajar siswa yang memiliki gaya Berpikir Abstrak adalah 29.95, sedangkan rata-rata hasil belajar siswa yang memiliki gaya Berpikir Konkrit adalah 20.00. Maka $\mathrm{H}_{0}$ ditolak, dan Ha diterima. (3) diperoleh hasil penelitian yang dilakukan oleh peneliti dapat dilihat hasil uji ANAVA yaitu Hasil Belajar siswa tidak Terdapat interaksi penggunaan multimedia dan gaya berpikir dalam mempengaruhi hasil belajar Bahasa Inggris
\end{abstract}

Kata Kunci: Pembelajaran Multimedia Macromedia Flash, Multimedia PowerPoint, Hasil belajar

Abstract: This study is a quasi-experimental research. The population in this study were all students of VIII class of Private MTs Darul Mursyid. Sample selection are randomly. The instrument used consisted of: (1) achievement test used in this study as many as 37 multiple-choice items (2) the student's learning style thinking as much as 15 items. The instrument has qualified content validity and construct validity and reliability coefficients. The data were analyzed using descriptive statistics and inferential analysis. Inferential analysis of data performed by Anava test $2 \times 2$ independent samples. The results showed that: (1) from the calculation results can be seen from the results obtained that average student learning outcomes are taught using learning Multimedia Macromedia Flash are 26.36, while average student learning outcomes are taught using learning Multimedia PowerPoint are 22.5, so that Ho refused and Ha accepted, (2) the estimates can be seen from the results obtained that the average student learning outcomes that have style Abstract Thinking are 29.95, while the average student learning outcomes that have style Concrete Thinking are 20.00, then Ho is rejected, and Ha accepted. (3) the results of research conducted by the researchers can be seen the results of ANAVA that student learning outcomes are meaning, There are no interactions multimedia usage and style of thinking in influencing the outcomes of learning English.

Keywords: Learning Multimedia Macromedia Flash, Learning Multimedia PowerPoint, Learning outcomes.

\section{PENDAHULUAN}

Bahasa Inggris adalah mata pelajaran yang sangat penting untuk dipelajari, pada dunia pendidikan yang terus berkembang menuntut setiap individu yang berada dalam lingkaran globalisasi pendidikan untuk ikut serta mempelajari Bahasa Inggris. Manfaat Bahasa Inggris memiliki lingkup yang begitu 
luas baik dalam hal pendidikan, teknologi, dunia kerja, bahkan sebagai media untuk bersosialisasi maupun menjalin kerja sama antar benua.

Realitas saat ini, banyak siswa merasa kesulitan dalam mempelajari dan menguasai pelajaran Bahasa Inggris di sekolah, hal ini berefek pada rendahnya hasil belajar Bahasa Inggris, begitu juga yang dialami oleh siswa MTs Swasta Darul Mursyid Tapanuli Selatan.

Mata pelajaran Bahasa Inggris diajarakan sebanyak enam les per minggu dengan rincian empat les mata pelajaran Bahasa Inggris dan dua les mata pelajaran story telling yang bertujuan untuk membiasakan siswa untuk berkomunikasi Bahasa Inggris dengan baik.

Muatan mata pelajaran Bahasa Inggris termasuk mata pelajaran yang lebih banyak les nya per minggu di kurikulum MTs. Swasta Darul Mursyid dibandingkan dengan mata pelajaran yang lain seperti mata pelajaran IPA maupun IPS. Namun hasil belajar siswa untuk mata pelajaran Bahasa Inggris masih tergolong rendah karena masih di bawah nilai Kriteria Ketuntasan Minimal (KKM) yang telah ditentukan oleh madrasah tersebut. Guru-guru yang mengampu mata pelajaran Bahasa Inggris ini pun adalah sarjana pendidikan bidang Bahasa Inggris.

Menurut Jean Piaget (dalam Schunk, 2012:331), proses belajar terdiri dari tiga tahapan, yakni asimilisasi, akomodasi, dan equilibrasi (penyeimbangan). Proses asimilasi adalah proses penyatuan (pengintegrasian) informasi baru ke struktur kognitif yang sudah ada dalam benak pebelajar. Proses akomodasi adalah penyesuaian struktur kognitif ke dalam situasi yang baru. Proses equilibrasi adalah penyesuaian berkesinambungan antara asimilasi dan akomodasi.

Namun pengajaran di kelas, guru hanya menggunakan buku cetak dan kurang memanfaatkan media pembelajaran, hal ini ditunjukkan ketika proses belajar mengajar yang masih bersifat konvensional, dan menjadikan proses pembelajaran monoton dan siswa menjadi bosan serta pembelajaran pun menjadi kurang menarik.

Selanjutnya sebagian siswa masih sulit mencerna dan memahami materi yang diajarkan karena adanya perbedaan karakter berpikir siswa di dalam suatu ruang kelas. Perbedaan gaya berpikir siswa ini menimbulkan perbedaan kemampuan pemahaman siswa terhadap materi yang diajarkan, sehingga hasil belajar siswa pun berbeda.

Menurut Benjamin Bloom (dalam Sudjana, 2009: 22-23) hasil belajar terbagi menjadi tiga ranah yaitu: (1) Ranah Kognitif, yaitu berkenaan dengan hasil belajar intelektual yang terdiri dari tujuh aspek yaitu pengetahuan, ingatan, pemahaman, aplikasi, analisis, sintesis, dan evaluasi; (2) Ranah Afektif, yaitu berkenaan dengan sikap yang terdiri dari lima spek, yakni penerimaan, jawaban atau reaksi, penelitian, organisasi, dan internalisasi; (3) Ranah Psikomotorik, yaitu berkenaan dengan hasil belajar ketrampilan dan kemampuan bertindak. Ada enam aspek ranah psikomotorik, yakni gerakan refleks, keterampilan gerakan dasar, kemampuan perceptual, keharmonisan atau ketepatan, gerakan keterampilan kompleks, dan gerakan ekspresif dan interpretatif.

Beberapa faktor yang menyebabkan rendahnya hasil belajar Bahasa Inggris siswa MTs. Swasta Darul Mursyid, antara lain:

Pertama, pembelajaran di kelas masih menggunakan model pembelajaran konvesional (ceramah), kurang melibatkan siswa dalam pembelajaran dan bersifat satu arah. Model pembelajaran ini akan merugikan siswa yang memiliki gaya berpikir konkrit karena siswa yang memiliki gaya berpikir konkrit akan sulit menerima pembelajaran yang bersifat verbal (lisan).

Kedua, pembelajaran lebih menekankan pada penguasaan grammar dan pemahaman bacaan daripada kompetensi komunikasi. Dalam pembelajaran Bahasa Inggris ada beberapa faktor untuk dapat menguasai keterampilan Berbahasa Inggris, antara lain; membaca (to read), menulis (to write), berbicara (to speak), dan mendengar (to listen), keempat faktor ini sangat terkait satu sama lain dan tidak dapat dipisahkan satu sama lain.

Ketiga, proses belajar dan praktek Bahasa Inggris hanya berlangsung dalam kelas. Keterampilan berbahasa Inggris dapat diraih tidak hanya di dalam kelas. Secara teoretis ataupun materi pembelajaran bisa didapat di dalam ruang kelas. Namun dalam keseharian (aktivitas sehari-hari) materi yang didapat di dalam kelas dapat dipraktekkan bersama di lingkungannya masing-masing.

Menurut Rusmadjadi (2010:35), pembelajaran Bahasa Inggris dengan cara yang monoton kurang memberi kesempatan kepada siswa berinteraksi dengan siswa yang lain. 
Pembelajaran berbicara Bahasa Inggris bukan sebatas pemberian pengetahuan yang bersifat hafalan (grammatically); akan lebih baik lagi apabila dalam pembelajaran berbicara Bahasa Inggris ada interaksi antara satu siswa dengan siswa lainnya.

Keempat, terbatasnya multimedia pembelajaran yang akan membuat pembelajaran akan lebih menarik. Saat pembelajaran di kelas guru tidak menggunakan multimedia pembelajaran karena pihak sekolah belum menyediakan multimedia tersebut.

Kelima, terdapat perbedaan gaya berpikir siswa dalam satu kelas, sehingga siswa berbeda dalam menerima materi pembelajaran yang diberikan guru. Pembelajaran seharusnya dapat mentransfer materi ke semua siswa yang memiliki gaya berpikir yang berbeda-beda pula Penggunaan multimedia dalam pembelajaran Bahasa Inggris diharapkan dapat membantu siswa dalam menerima dan memahami materi yang disampaikan oleh guru di dalam kelas.

$$
\text { Frankel (dalam Patmonodewo }
$$

2001:116) mendefinisikan berpikir sebagai pembentukan ide-ide, reorganisasi dan pengalaman pengalaman seseorang dan pengorganisasian informasi-informasi ke dalam bentuk yang khas. Ahmadi (2003:83) mendefinisikan berpikir sebagai aktivitas psikis yang potensial, dan terjadi apabila seseorang menyimpan problem (masalah) yang harus dipecahkan.

Menurut Albrecht (2003:67), berpikir merupakan proses menyikapi sebagai pengetahuan, baik pengetahuan berupa bentuk suara atau rasa yang berasal dari dalam ingatan. Pandangan ini juga relevan dengan yang dikemukakan oleh Award (2004:102), bahwa berpikir merupakan proses pengklasifikasian, perbandingan dan penilaian terhadap pengetahuan berdasarkan kepercayaan, keyakinan dan nilai-nilai yang tertata, lalu berubah menjadi bentuk strategi yang menghasilkan pengungakapan secara bahasa atau tindakan.

Penelitian ini bertujuan: (1) untuk mengetahui hasil belajar Bahasa Inggris siswa yang diajarkan dengan menggunakan multimedia Macromedia Flash lebih tinggi daripada siswa yang diajarkan dengan menggunakan multimedia Power Point. (2) untuk mengetahui hasil belajar Bahasa Inggris siswa yang memiliki gaya berpikir abstrak lebih tinggi dibandingkan siswa yang memiliki gaya berpikir konkrit. (3) untuk mengetahui adanya interaksi antara penggunaan multimedia dan gaya berpikir dalam memberikan pengaruh terhadap hasil belajar Bahasa Inggris.

Burton (2002:99) menyatakan

"Learning is a change in the individual due to instruction of that individual and his environment, which fells a need and makes him more capable of dealing adequately with his environment". Dalam pengertian ini terdapat kata change atau "perubahan" yang berarti bahwa seseorang setelah mengalami proses belajar, akan mengalami perubahan tingkah laku, baik aspek pengetahuannya, keterampilannya maupun aspek sikapnya. Misalnya dari tidak tahu sama sekali menjadi tahu, pandai dan bahkan mahir.

Menurut Sudjana (2005:3), bahwa hasil belajar siswa pada hakikatnya adalah perubahan tingkah laku yang telah terjadi melalui proses pembelajaran. Perubahan tingkah laku tersebut berupa kemampuan-kemapuan siswa setelah aktifitas belajar yang menjadi hasil perolehan belajar. Dengan demikian hasil belajar adalah perubahan yang terjadi pada individu setelah mengalami pembelajaran. Hasil belajar Bahasa Inggris merupakan data yang menunjukkan penguasaan Bahasa Inggris yang meliputi empat keterampilan berbahasa, yaitu listening, speaking, reading dan writing.

Mayer (2009:119), mendefinisikan multimedia sebagai presentasi materi dengan menggunakan kata-kata sekaligus gambargambar yang dimaksud dengan kata disini adalah materinya disajikan dengan verbal form atau bentuk verbal, misalnya menggunakan teks kata-kata yang tercetak atau terucapkan.

Puspitosari (2010:67) dalam mengemukakan bahwa multimedia merupakan perpaduan antara berbagai media atau format file yang berupa teks, gambar (vektor atau bitmap), grafik, sound, animasi, video interaksi dan lain-lain, sedangkan dari Wikipedia Inggris ensiklopedia berbahasa Inggris pengertian multimedia adalah penggunaan komputer untuk menyajikan dan menggabungkan teks, suara, gambar, animasi dan video dengan alat bantu (tool) dan koneksi (link) sehingga pengguna dapat bernavigasi, berinteraksi, berkarya, dan berkomunikasi.

Dari beberapa pengertian multimedia yang dikemukakan oleh para ahli tersebut dapat ditarik kesimpulan bahwa multimedia merupakan suatu gabungan antara teks, gambar, grafis, animasi, audio dan video, serta cara penyampaiannya interaktif sehingga dapat 
membuat suatu pengalaman belajar bagi siswa seperti dalam kehidupan nyata disekitarnya. Multimedia dapat berfungsi menjadi sebuah sistem karena merupakan sekumpulan objek yang berhubungan dan bekerjasama untuk menghasilkan suatu hasil yang diinginkan. Didalam penggunaan multimedia memerlukan hardware (perangkat keras) yang berfungsi untuk memfasilitasi penyampaian materi dan software (perangkat lunak) yang berisi program-program yang akan disampaikan.

Macromedia Flash Professional 8.0 dibuat oleh perusahaan software macromedia untuk keperluan membuat suatu aplikasi web yang interaktif dan menarik. Macromedia Flash 8.0 sering digunakan untuk membuat animasi dan untuk keperluan lain seperti membuat game dan tutorial. Aplikasi Macromedia Flash 8.0 adalah aplikasi yang dapat menampilkan teks, gambar, animasi, dan audio secara bersama maka sangat mungkin apabila Macromedia Flash 8.0 digunakan sebagai sarana pengembangan media pembelajaran (Dikse, 2010:1).

Dalam proses belajar mengajar kehadiran media mempunyai arti yang cukup penting. Dalam kegiatan tersebut ketidak jelasan bahan-bahan yang disampaikan dapat dibantu dengan menghadirkan media sebagai perantara kerumitan bahan yang akan disampaikan. Kemajuan teknologi informasi dan komunikasi mempengaruhi banyak sektor kehidupan guru yang bergelut di bidang pendidikan dan pengajaran juga tidak luput dari pengaruh tersebut. Guru dituntut untuk mengikuti perkembangan teknologi, terutama sekali Teknologi Informasi dan Komunikasi (TIK) yang berkembang sangat pesat dalam beberapa tahun terakhir. Apabila guru tidak mampu mengikuti kecepatan perubahan teknologi, maka dikhawatirkan guru akan gagal menjalankan fungsinya sebagai pengajar dan pendidik.
Rumusan masalah pada penelitian ini adalah: (1) Apakah hasil belajar Bahasa Inggris yang diajarkan dengan menggunakan multimedia Macromedia Flash lebih tinggi dari siswa yang diajarkan dengan menggunakan multimedia PowerPoint ?, (2) Apakah hasil belajar Bahasa Inggris siswa yang memiliki gaya berpikir abstrak lebih tinggi dibandingkan siswa yang memiliki gaya berpikir konkrit ?, (3) Apakah terdapat interaksi penggunaan multimedia dengan gaya berpikir terhadap hasil belajar Bahasa Inggris?.

\section{METODE}

Populasi dalam penelitian ini adalah seluruh siswa kelas VIII MTs Swasta Darul Mursyid yang terdiri dari 5 kelas yaitu VIII-1 sampai dengan VIII-5 dengan jumlah keseluruhan adalah 129 orang siswa. Teknik pengambilan sampel yang digunakan adalah cluster random sampling yaitu sampel yang diambil berdasarkan kelompok (kelas) secara acak, dari 5 kelas terpilih kelas VIII-1 dan VIII5.

Jenis penelitian yang digunakan adalah quasi eksperimen (eksperimen semu) dan desain yang digunakan adalah desain faktorial $2 \times 2$.

Teknik analisis data yang digunakan untuk menguji hipotesis penelitian digunakan teknik analisis data dengan menggunakan analisis varians (ANAVA) dengan dua jalan (desain faktorial $2 \times 2$ ) dengan taraf signifikan 0.05 . Sebelum hipotesis diuji terlebih dulu dilakukan uji persyaratan terhadap data yang dikumpulkan yaitu dengan menggunakan; (1) uji normalitas (2) uji homogenitas. Sebagai uji persyaratan analisis dilakukan pengujian normalitas, dengan menggunakan uji Lilifors. Setelah uji normalitas, dilakukan uji homogenitas dengan menggunakan uji $\mathrm{F}$ dan uji Barlett. Uji lanjut yang digunakan adalah uji scheffe.

Tabel 2. Desain Faktorial $2 \times 2$

\begin{tabular}{|c|c|c|}
\hline $\begin{array}{c}\text { Strategi } \\
\text { Pengelajaran }\end{array}$ & $\begin{array}{c}\text { Multimedia } \\
\text { Macromedia Flash } \\
\left(\mathbf{A}_{\mathbf{1}}\right)\end{array}$ & $\begin{array}{c}\text { Multimedia PowerPoint } \\
\left(\mathbf{A}_{2}\right)\end{array}$ \\
\hline Gaya Berpikir & $\mathrm{A}_{1} \mathrm{~B}_{1}$ & $\mathrm{~A}_{2} \mathrm{~B}_{1}$ \\
\hline Abstrak $\left(\mathrm{B}_{1}\right)$ & $\mathrm{A}_{1} \mathrm{~B}_{2}$ & $\mathrm{~A}_{2} \mathrm{~B}_{2}$ \\
\hline Konkrit $\left(\mathrm{B}_{2}\right)$ & & \\
\hline
\end{tabular}

Untuk memperoleh data yang menggunakan teknik pengumpulan data. diperlukan dalam penelitian ini, maka peneliti Adapun teknik pengumpulan data yang peneliti 
pergunakan adalah teknik tes dan kuesioner baik untuk mengumpulkan data tentang hasil belajar Bahasa Inggris, maupun gaya berpikir siswa.

Instrument yang digunakan dalam penelitian ini adalah menggunakan dua jenis bentuk tes yaitu: (1) instrument tes hasil belajar Bahasa Inggris siswa dan, (2) instrument tes gaya berpikir siswa dalam belajar. Acuan penelitian memilih instrument tes untuk alat pengumpulan data berdasarkan pendapat
Arikunto (2009:150) yang menyebutkan tes adalah serentetan pernyataan yang digunakan untuk mengukur pengetahuan inteligensi atau kemampuan yang dimiliki individu atau kelompok.

\section{HASIL PENELITIAN}

Rangkuman hasil uji normalitas untuk semua kelompok sampel ditunjukkan pada table berikut ini:

Tabel 3. Rangkuman Hasil Pengujian Normalitas Data (Uji Liliefors)

\begin{tabular}{|c|l|c|c|c|c|}
\hline No. & \multicolumn{1}{|c|}{ Kelompok Sampel } & N & Lohitung & Lotabel & Ket \\
\hline 1 & $\begin{array}{l}\text { Skor Hasil Belajar Bahasa inggris siswa yang diajarkan dengan } \\
\text { Multimedia Macromedia Flash }\end{array}$ & 25 & $\mathbf{0 . 0 8 1}$ & $\mathbf{0 . 1 7 3}$ & Normal \\
\hline 2 & $\begin{array}{l}\text { Skor Hasil Belajar Bahasa inggris siswa yang diajarkan dengan } \\
\text { pendekatan Multimedia PowerPoint }\end{array}$ & 24 & $\mathbf{0 . 0 8 3}$ & $\mathbf{0 . 1 7 3}$ & Normal \\
\hline 3 & $\begin{array}{l}\text { Skor Hasil Belajar Bahasa inggris siswa berpikir abstrak yang } \\
\text { diajarkan dengan Multimedia Macromedia Flash }\end{array}$ & 11 & $\mathbf{0 . 0 8 9}$ & $\mathbf{0 . 2 4 9}$ & Normal \\
\hline 4 & $\begin{array}{l}\text { Skor Hasil Belajar Bahasa inggris siswa berpikir kongkrit yang } \\
\text { diajarkan dengan Multimedia Macromedia Flash }\end{array}$ & 14 & $\mathbf{0 . 1 1 7}$ & $\mathbf{0 . 2 2 7}$ & Normal \\
\hline 5 & $\begin{array}{l}\text { Skor Hasil Belajar Bahasa inggris siswa berpikir abstrak yang } \\
\text { diajarkan dengan Multimedia PowerPoint }\end{array}$ & 11 & $\mathbf{0 . 0 8 9}$ & $\mathbf{0 . 2 4 9}$ & Normal \\
\hline 6 & $\begin{array}{l}\text { Skor Hasil Belajar Bahasa inggris siswa berpikir kongkrit yang } \\
\text { diajarkan dengan Multimedia PowerPoint }\end{array}$ & 13 & $\mathbf{0 . 1 1 3}$ & $\mathbf{0 . 2 3 4}$ & Normal \\
\hline
\end{tabular}

Rangkuman hasil perhitungan homogenitas (Uji F) untuk kelompok data dapat dilihat dari tabel dibawah ini:

Tabel 4. Hasil Perhitungan Homogenitas (Uji F) untuk Kelompok Data (Pendekatan Pembelajaran)

\begin{tabular}{|l|l|l|l|l|l|}
\hline No. & $\begin{array}{l}\text { Pendekatan } \\
\text { Pembelajaran }\end{array}$ & Varians & Fhitung & Ftabel & Keterangan \\
\hline 1 & $\begin{array}{l}\text { Pendekatan Multimedia } \\
\text { Macromedia Flash }\end{array}$ & 35.164 & \multirow{2}{*}{1.085} & 4.04 & Homogen \\
\hline 2 & $\begin{array}{l}\text { Pendekatan Multimedia } \\
\text { PowerPoint }\end{array}$ & 38.168 & & \\
\hline
\end{tabular}

Setelah data diolah, untuk menguji 3 (tiga) hipotesis di atas di Uji hipotesis dengan menggunakan analisis varians (Anava 2x2) pada tabel 5 berikut.

Tabel 5. Ringkasan Perhitungan ANAVA Faktorial 2x2

\begin{tabular}{|l|l|l|l|l|l|}
\hline \multicolumn{1}{|c|}{ Source } & $\begin{array}{c}\text { Type III Sum } \\
\text { of Squares }\end{array}$ & \multicolumn{1}{|c|}{ df } & \multicolumn{1}{c|}{$\begin{array}{c}\text { Mean } \\
\text { Square }\end{array}$} & \multicolumn{1}{c|}{ F } & \multicolumn{1}{c|}{ Sig. } \\
\hline Corrected Model & $1016.578^{\mathrm{a}}$ & 3 & 338.859 & 17.179 & .000 \\
\hline Intercept & 29929.054 & 1 & 29929.054 & 1517.313 & .000 \\
\hline berpikir & 833.938 & 1 & 833.938 & 42.278 & .000 \\
\hline metode & 194.906 & 1 & 194.906 & 9.881 & .003 \\
\hline berpikir * metode & .001 & 1 & .001 & .000 & .993 \\
\hline Error & 887.626 & 45 & 19.725 & & \\
\hline Total & 31243.000 & 49 & & & \\
\hline Corrected Total & 1904.204 & 48 & & & \\
\hline
\end{tabular}

Hasil belajar Bahasa Inggris yang diajarkan dengan menggunakan Multimedia Macromedia Flash lebih tinggi dari siswa yang diajarkan dengan menggunakan multimedia PowerPoint.

Pengujian hipotesis statistik untuk pembelajaran Pembelajaran Multimedia 
Macromedia Flash dan Pembelajaran multimedia PowerPoint adalah sebagai berikut.

Ho : $\mu \mathrm{A} 1 \leq \mu \mathrm{A} 2 \quad ; \quad \mathrm{Ha}: \mu \mathrm{A} 1 \geq \mu \mathrm{A} 2$

Pernyataan hipotesis tersebut adalah :

Ho = Hasil belajar Bahasa Inggris yang diajarkan dengan menggunakan Multimedia Macromedia Flash lebih rendah dari siswa yang diajarkan dengan menggunakan multimedia PowerPoint.

$\mathrm{Ha}=$ Hasil belajar Bahasa Inggris yang diajarkan dengan menggunakan Multimedia Macromedia Flash lebih tinggi dari siswa yang diajarkan dengan menggunakan multimedia PowerPoint.

Dari hasil perhitungan yang diperoleh yang dapat dilihat dari hasil penelitian diperoleh bahwa rara-rata hasil belajar siswa yang diajarkan dengan menggunakan Pembelajaran Multimedia Macromedia Flash adalah 26.36, sedangkan rara-rata hasil belajar siswa yang diajarkan dengan menggunakan Pembelajaran multimedia PowerPoint 22.5. Hasil analisis varians menunjukkan bahwa terdapat perbedaan Hasil pembelajaran siswa yang di ajar dengan menggunakan Pembelajaran Multimedia Macromedia Flash dengan siswa yang di ajar dengan menggunakan Pembelajaran multimedia PowerPoint yang signifikan. Hal ini dapat ditunjukkan dari $\mathrm{F}_{\text {hitung }}=9.881>\mathrm{F}_{\text {tabel }}=4,00$, sehingga Ho ditolak dan Ha diterima. Dengan demikian dapat disimpulkan bahwa Hasil belajar Bahasa Inggris yang diajarkan dengan menggunakan Multimedia Macromedia Flash lebih tinggi dari siswa yang diajarkan dengan menggunakan multimedia PowerPoint.

Hasil belajar Bahasa Inggris siswa yang memiliki gaya Berpikir Abstrak lebih tinggi dari siswa yang memiliki gaya Berpikir Konkrit.

Pengujian hipotesis statistik untuk gaya

Berpikir Abstrak dan siswa yang memiliki gaya Berpikir Konkrit adalah sebagai berikut.

Ho $: \mu \mathrm{A} 1 \leq \mu \mathrm{A} 2 \quad ; \quad$ Ha $: \mu \mathrm{A} 1 \geq \mu \mathrm{A} 2$ Pernyataan hipotesis tersebut adalah :

$\mathrm{H}_{0}=$ Hasil belajar Bahasa Inggris siswa yang memiliki gaya Berpikir Abstrak lebih rendah dari siswa yang memiliki gaya Berpikir Konkrit.

$\mathrm{Ha}=$ Hasil belajar Bahasa Inggris siswa yang memiliki gaya Berpikir Abstrak lebih tinggi dari siswa yang memiliki gaya Berpikir Konkrit.
Dari hasil perhitungan yang diperoleh yang dapat dilihat dari hasil penelitian diperoleh bahwa Rara-rata hasil belajar siswa yang memiliki gaya Berpikir Abstrak adalah 29.95, sedangkan rara-rata hasil belajar siswa yang memiliki gaya Berpikir Konkrit adalah 20.00. Hasil analisis varians menunjukkan bahwa terdapat perbedaan Hasil belajar siswa yang memiliki gaya Berpikir Abstrak dengan siswa yang memiliki gaya Berpikir Konkrit yang signifikan. Hal ini dapat ditunjukkan dari uji ANAVA yaitu Fhitung $=42.278$, sedangkan $\mathrm{F}_{\text {tabel }}=4.00$. karena $\mathrm{F}_{\text {hitung }}>\mathrm{F}_{\text {tabel }}$ maka $\mathrm{H}_{0}$ ditolak. Dengan demikian dapat disimpulkan bahwa Hasil belajar Bahasa Inggris siswa yang memiliki gaya Berpikir Abstrak lebih tinggi dari siswa yang memiliki gaya Berpikir Konkrit.

Terdapat interaksi penggunaan multimedia dan gaya berpikir dalam mempengaruhi hasil belajar Bahasa Inggris.

Pengujian hipotesis statistik untuk pembelajaran Pembelajaran dan gaya berpikir belajar siswa adalah sebagai berikut.

$$
\text { Ho : } \mu \mathrm{A} 1 \leq \mu \mathrm{A} 2 ; \quad \mathrm{Ha}: \mu \mathrm{A} 1 \geq \mu \mathrm{A} 2
$$

Pernyataan hipotesis tersebut adalah :

Ho = Tidak Terdapat interaksi penggunaan multimedia dan gaya berpikir dalam mempengaruhi hasil belajar Bahasa Inggris.

$\mathrm{Ha}=$ Terdapat interaksi penggunaan multimedia dan gaya berpikir dalam mempengaruhi hasil belajar Bahasa Inggris.

Dari hasil perhitungan yang diperoleh yang dapat dilihat dari hasil penelitian diperoleh bahwa rara-rata hasil belajar siswa yang diajarkan dengan menggunakan Pembelajaran Multimedia Macromedia Flash adalah 26.36, sedangkan rara-rata hasil belajar siswa yang diajarkan dengan menggunakan Pembelajaran multimedia PowerPoint 22.5. dan Rara-rata hasil belajar siswa yang memiliki gaya Berpikir Abstrak adalah 29.95, sedangkan rara-rata hasil belajar siswa yang memiliki gaya Berpikir Konkrit adalah 20.00.

Pembelajaran dengan pendekatan Multimedia PowerPoint dan pembelajaran Multimedia Macromedia Flash dapat mengakomodasi tingkatan Hasil Belajar yaitu Hasil Belajar penggunaan multimedia dan gaya berpikir dalam mempengaruhi hasil belajar Bahasa Inggris. Hal ini dapat dilihat dari Gambar 1 berikut ini. 


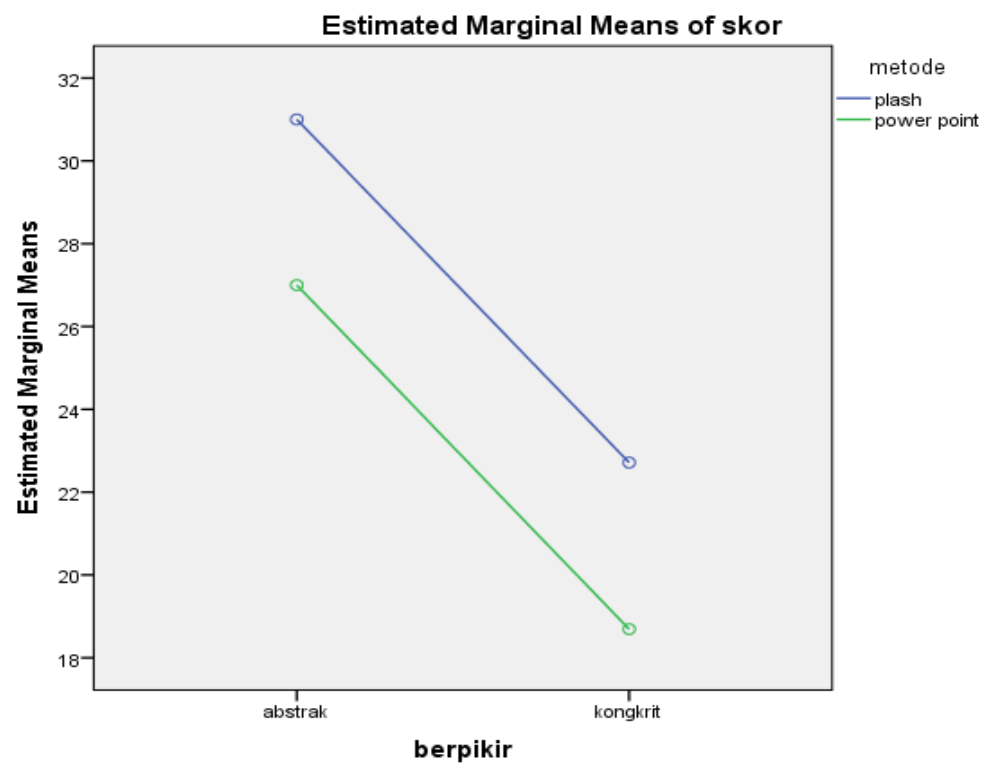

Gambar 1.Interaksi Strategi Pembelajaran dan Gaya Belajar terhadap Hasil Belajar Gambar Bahasa Inggris.

\section{PEMBAHASAN}

Hasil Belajar Bahasa inggris siswa berdasarkan perolehan data di atas dapat disimpulkan bahwa peningkatan Hasil Belajar Bahasa inggris siswa yang diajarkan dengan pendekatan Multimedia Macromedia Flash lebih tinggi dari siswa yang diajarkan dengan Multimedia PowerPoint. Hal ini sejalan dengan Schunk (2012) bahwa teori konstruktivisme adalah suatu teori belajar yang menekankan bahwa para kemampuan siswa dalam membangun sendiri pengetahuannya sehingga siswa cendrung untuk memahami dan menganalisis pengetahuan yang dimilikinya. Artinya hasil pembelajaran siswa yang di ajar dengan menggunakan Strategi Pembelajaran Multimedia Macromedia Flash lebih tinggi dibandingkan dengan siswa yang di ajar dengan menggunakan Pembelajaran Multimedia Power-Point terhadap hasil belajar bahasa inggris siswa MTs Swasta Darul Mursyid Tapanuli Selatan.

Hasil penelitian ini sejalan dengan pendapat Madcom (2004:12), Macromedia Flash 8.0 adalah program grafis yang diperuntukan untuk motion atau gerak dan dilengkapi dengan script untuk programming (action script) dengan program ini memungkinkan pembuatan animasi media interaktif, game. Arno Prasetio (2006:9), juga mengemukakan bahwa Macromedia Flash 8.0 adalah suatu suatu software animasi yang dapat digunakan untuk mempermudah penyampaian suatu konsep yang bersifat abstrak yang dalam penerapannya menggunakan komputer dan media imager proyector. Software ini mempunyai banyak keunggulan dibandingkan dengan software animasi lainnya di antaranya adalah program yang berorientasi objek, mampu mendesain gambar berbasis vector, kemampuannya menghasilkan animasi gerak dan suara dan dapat dipergunakan sebagai software pembuat situs website, serta masih banyak keunggulan lainnya dibandingkan dengan software animasi lain.

Hal ini juga sejalan dengan hasil penelitian Amir Hulopi (2010) dengan tujuan penelitian untuk melihat perbedaan kemampuan penalaran matematika siswa yang dibelajarkan menggunakan multimedia pembelajaran interaktif dengan yang dibelajarkan menggunakan media powerpoint. Penelitian dilaksanakan di SMP Negeri 1 Gorontalo dengan sampel sebanyak 52 orang. Dari penelitian diperoleh bahwa kemampuan penalaran matematika siswa yang dibelajarkan menggunakan multimedia pembelajaran interaktif lebih tinggi dibandingkan dengan siswa yang dibelajarkan menggunakan media powerpoint.

Lain halnya dengan Multimedia PowerPoint, Microsoft Power-Point merupakan salah satu program berbasis multimedia. Di dalam komputer, biasanya program ini sudah 
dikelompokkan dalam program Microsoft Office. Program ini dirancang khusus untuk menyampaikan presentasi, baik yang diselenggarakan oleh perusahaan, pemerintah, pendidikan, maupun perorangan, dengan berbagai fitur menu yang mampu menjadikannya sebagai media komunikasi yang menarik. PowerPoint sangat banyak digunakan saat ini apalagi oleh kalangan perkantoran dan pebisnis, para pendidik, siswa dan trainer untuk presentasi (Abdul Razaq, 2007: 7).

Hasil penelitian ini sejalan dengan pendapat Gregore (2004:150), realitas bagi para pemikir dengan gaya berpikir abstrak adalah dunia teori metafsisis dan pemikiran abstrak. Orang yang memiliki gaya berpikir abstrak suka berpikir dalam konsep dan menganalisis informasi. Orang seperti ini akan sangat menghargai orang-orang dan peristiwaperistiwa yang teratur dan rapi. Adalah mudah bagi mereka untuk meneropong hal-hal penting seperti titik-titik kunci dan detail-detail penting. Proses berpikir mereka logis, rasional dan intelektual.

Guru-guru yang mengajar di dalam kelas diharapkan mampu untuk mengarahkan anak dalam aktivitas-aktivitas belajar, mampu memotivasi siswa untuk aktif dalam kelompokkelompok belajar. Pada saat belajar kemampuan seorang guru sangat menentukan keberhasilan belajar siswa, untuk itu pembelajaran yang diterapkan oleh guru harus bervariasi. Dengan menerapkan pembelajaran yang tepat memungkinkan siswa yang memiliki gaya Berpikir Abstrak memiliki hasil belajar bahasa inggris lebih baik. Menurut Skinner (Schunkl, 2012) Jika respon siswa baik maka harus segera diberi penguatan positif agar respon tersebut lebih baik lagi sehingga hasil belajarnya juga baik. Hasil belajar yang meningkat dapat mempengaruhi kenikmatan di dalam belajar sehingga siswa terus termotivasi untuk belajar.

Pengelompokan siswa kedalam kelompok Hasil Belajar gaya berpikir dalam mempengaruhi hasil belajar Bahasa Inggris didasarkan pada kriteria yang telah ditentukan yang dituangkan di bab sebelumnya. Dalam penelitian ini, faktor Hasil Belajar dikaitkan dengan pembelajaran. Sebagaimana yang diungkapkan oleh Maswin (2010:89) dalam mengemukakan bahwa multimedia merupakan perpaduan antara berbagai media atau format file yang berupa teks, gambar, grafik, sound, animasi, video interaksi dan lain-lain, sedangkan dari Wikipedia Inggris ensiklopedia berbahasa Inggris pengertian multimedia adalah penggunaan komputer untuk menyajikan dan menggabungkan teks, suara, gambar, animasi dan video dengan alat bantu dan koneksi sehingga pengguna dapat bernavigasi, berinteraksi, berkarya, dan berkomunikasi. Sementara gaya berpikir merupakan kemampuan seseorang untuk menciptakan hal baru, dapat memberikan keberhasilan dan kepuasan yang dapat meningkatkan kualitas hidup kesejateraan fisik dan mental diri seseorang maupun orang lain. Dalam proses pembelajaran, gaya berpikir termasuk faktor internal atau bagian dari karakteristik siswa yang ikut diperhatikan dalam mencapai hasil belajar siswa.

Hasil penelitian menunjukkan bahwa secara signifikan tidak terdapat interaksi antara penggunaan pembelajaran dan gaya berpikir siswa dalam mempengaruhi Hasil Belajar Bahasa inggris. Dengan kata lain selisih skor rata-rata Hasil Belajar Bahasa inggris siswa dan skor rata-rata gaya berpikir yang diajar dengan pendekatan Multimedia PowerPoint tidak berbeda secara signifikan dengan yang diajar dengan pembelajaran Multimedia Macro-media Flash. Hal ini menunjukkan bahwa pembelajaran dengan pendekatan Multimedia PowerPoint dan pembelajaran Multimedia Macromedia Flash dapat menga-komodasi tingkatan Hasil Belajar yaitu Hasil Belajar gaya Berpikir Abstrak dan siswa yang memiliki gaya Berpikir Konkrit. Artinya hasil pembelajaran siswa Tidak Terdapat interaksi penggunaan multimedia dan gaya berpikir dalam mempengaruhi hasil belajar Bahasa Inggris.

Hasil penelitian ini sejalan dengan hasil penelitian yang dilakukan oleh Angesti Nugraheni (2012) yang berjudul Pengaruh penggunaan media pembelajaran dan gaya belajar terhadap prestasi belajar mahasiswa pada mata kuliah konsep kebidanan. Dari penelitian ini ditemukan untuk interaksi antara media pembelajaran dan gaya belajar terhadap prestasi belajar siswa sebesar 0.27 pada taraf signifikan 0.05 , hal ini berarti hipotesis nol diterima, sehingga dapat disimpulkan bahwa tidak ada interaksi antara media pembelajaran dan gaya belajar terhadap prestasi belajar.

Hasil penelitian ini juga sejalan dengan hasil penelitian yang dilakukan oleh Hikmawati (2013) yang berjudul Pengaruh penggunaan media pembelajaran dan gaya kognitif terhadap hasil belajar Matematika siswa kelas VIII madrasah tsanawiyah. Dari penelitian ini 
ditemukan tidak terdapat interaksi yang signifikan antara penggunaan media pembelajaran dan gaya kognitif terhadap hasil belajar siswa. Gaya kognitif tidak mempengaruhi hubungan media pembelajaran terhadap hasil belajar Matematika siswa. Tidak signifikannya perbedaan nilai rata-rata hasil belajar siswa mungkin disebabkan oleh peningkatan pemahaman konsep gaya kognitif field independent belum memadai untuk transfer.

\section{PENUTUP}

Berdasarkan hasil penelitian dan pembahasan yang dikemukakan sebelumnya, maka dapat ditarik beberapa kesimpulan dibawah ini :

1. Hasil belajar Bahasa Inggris yang diajarkan dengan menggunakan Multimedia Macromedia Flash lebih tinggi dari siswa yang diajarkan dengan menggunakan multimedia PowerPoint.

2. Hasil belajar Bahasa Inggris siswa yang memiliki gaya Berpikir Abstrak lebih tinggi dari siswa yang memiliki gaya Berpikir Konkrit.

3. Tidak Terdapat interaksi penggunaan multimedia dan gaya berpikir dalam mempengaruhi hasil belajar Bahasa Inggris.

\section{DAFTAR PUSTAKA}

Ahmadi, A, Uhbiyati, N. (2001). Ilmu Pendidikan. Jakarta: Rineka Cipta.

Ahmadi, A. Dan Supriyono, W. (1991). Psikologi Belajar. Jakarta: Rineka Cipta.

Albrecht. (2003). Erain Power. Learn to Improve Your Thinkings Skills: Daya Pikir, Metode Peningkatan Potensi Berpikir. Semarang: Dahara Prize.

Andi. (2006). Special Workshop Membuat Presentasi Imteraktif Dengan Macromedia Flash 8. Semarang: Penerbit ANDI.

Anjarningsih, Harwintha Yuhria. (2010). Otak dan Kemampuan Berbahasa. Yokyakarta: Pustaka Rihama.

Arikunto, S. (2003). Dasar-Dasar Evaluasi Pendidikan. Jakarta: Bumi Aksara.

Arikunto, suharsimi. (2009). Prosedur Penelitian: Suatu Pendekatan Praktik. Jakarta: RinekaCipta.

Artono, Masduki, M. Sukirman. (2008). English in Focus for Grade VIII Junior High School (SMP/MTs). Jakarta: Pusat
Perbukuan, Departemen Pendidikan Nasional.

Award. (2004). Kembangkang Potensi Diri Anda Sepenuhnya: Kiat Meraih Sukses Sesuai Tuntutan Islam. Yogyakarta: Mitra Pustaka.

Binanto, Iwan. (2010). Multimedia Digital (Dasar Teori dan Pengembangannya). Yogyakarta: Andi.

Bell Gredler, E. Margaret. (1991). Belajar dan Membelajarkan. Jakarta: CV. Rajawali.

Brown, J.D. (2009). The Elements of Language Curriculum. NY: Heinle Pub.

Burton-Roberts, Noel. (1997). Analysing Sentences. London: Longman.

Budiningsih, C. Asri, (2012). Belajar dan Pembelajaran. Jakarta: PT. Rineka Cipta.

Butler. (1986). lets you arrange your tasks in its fully customizable configuration. There, you can assign one or more triggers to a given task.

BSNP. (2006). Peraturan Menteri Pendidikan Nasional Republik Indonesia. Menteri Pendidikan Nasional.

Depdiknas. (2006). Panduan Pengembangan Bahan Ajar. Jakarta : Direktorat Pembinaan SMA, Dirjen Mandikdasmen, Depdiknas.

Depdiknas. (2005). Peraturan Pemerintah Republik Indonesia Nomor 19 Tahun 2005 Tentang standar Pendidikan Nasional

Deporter, B. Dan Hernacki, M. (2003). Quantum Learning (Penerjemah: Abdurrahman, A.) Bandung: Kaifa.

Dikse, I Wayan. (2010). Animasi dengan Flash 8. Yogyakarta: Jakarta: Kencana Prenada Media Group.

Dimyati dan Mudjiono. (2010). Belajar dan Pembelajaran. Jakarta: Rineka Cipta.

Dimyati, Mudjiono. (2002). Belajar dan Pembelajaran. Bandung. PT Rineka Cipta.

Djatmika, Agus Dwi, Ida Kusuma. (2014). Passport to The World, A Fun and Easy English Book for Grade VIII of Junior High Schools. Solo: PT. Tiga Serangkai Pustaka Mandiri.

Dryden G, Vos J. (2002). Revolusi Cara Belajar. Bandung: Kaifa

Fanani, A. Zainul. (2006). Tip dan Trik Animasi Macromedia Flash-Menyingkap Rahasia Teknik Animasi. Yokyakarta: Graha Ilmu.

Hackbarth, S. (1996). The Educational Technology Hand-book A Comprehensive 
Guide Process and Products for Learning. New Jersey: Educational Technology Publications.

Hadi Ariesto Sutopo. (2003). Multimedia Interaktif dengan Flash. Yogyakarta: Graha Ilmu.

Haryanto, Marliani. (2012). Blak-Blakan Bahas Mapel Bahasa Inggris SMA. Yogyakarta: Cabe Rawit.

Istiono, Wirawan. (2008). Education Game with flash 8.0. Jakarta: PT Elex Media Komputindo.

Jalaluddin dan Idi, Abdullah. (2011). Filsafat Pendidikan-Manusia, Filsafat, dan Pendidikan. Jakarta: Raja Grafindo Persada.

Jubilee, Enterprise. (2013). Tip dan Trik PowerPoint 2013-Mengupas Fitur-fitur Terbaru Tombol Shortcut, dan Cara Cepat Menguasai PowerPoint 2013. Jakarta: PT. Elex Media Komputindo.

Jubilee, Enterprise. (2014). 11 Trend Presentasi PowerPoint yang Amazing. Jakarta: PT. Elex Media Komputindo.

K. Abdul Hamid. (2104). Teori Belajar dan Pembelajaran. Medan: Program Pascasarjana Universitas Negeri Medan.

Kartono, T. (1997). Mengenal analisis tes (pengantar ke program computer ANATES). Bandung: jurusan psikologi dan bimbingan FIP IKIP.

Kemp, Jerrold E. (1994). Designing Effective Instruction. New York: Mcmillan College Publishers.Online http://library.nu. diakses tgl. 29 Januari 2015.

Kirkwood dan Symington, Lobby J.T. (1996). Belajar Bagaimana Belajar. Salatiga: BPT Gunung Mulia.

Madcoms. (2006). Mahir Dalam 7 Hari Macromedia Flash Pro 8. Yogyakarta: Andi Offset.

Madcom. (2004). Membuat Animasi Kartundengan Macromedia Flash MX 2004. Yogyakarta: Andi.

Manurung, Altur. S.S. (2005). Fokus Bahasa Inggris untuk SMP dan MTs. Jakarta: Erlangga.

Mas'ud, Fuad. (1987). Essentials Of English Grammar a Prctical Guide. Yogyakarta: BPFE.

Mayer, R. E. (2009). Multimedia Learning: Prinsip-prinsip dan Aplikasi, Yogyakarta: Pustaka Pelajar.

Muhibbin. (2014). Psikologi pendidikan, Bandung: Rosdakarya.
Ngalim Purwanto. (1997). Psikologi Pendidikan. Bandung: PT. Remaja Rosdakarya.

Puspitosari, Heni A. (2010). Membuat Presentasi Multimedia. Yogyakarta: Skripta. Media Creative.

Prasetio, Dimas Arno. (2006). Kenalan dengan Action Script 2.0 pada Flash MX, (http://ikc.depsos.go.id/pengantar/dimasa rno-actionscript.php, diunduh 17 Maret 2015).

Ramadianto, Anggara Yuda. (2008). Membuat Gambar Vektor dan Animasi Atraktif dengan Flash 8. Bandung: Yrama Widia.

Reddi, Usha V. \& Mishra, Sanjaya. (2003). Educational Multimedia AHandbook for TeacherDevelopers. New Delhi: Graphic Shield.

Roblyer, M. D. (2003). Technology and Theoops! Effect: Finding A bias AgainstWord Processing. Learning and Leading With Technology, 24(7), 14-16.

Rusmadjadi. (2010). Terampil Berbahasa Inggris. Jakarta. PT Indeks.

Sanjaya, Wina. (2006). Strategi Pembelajaran. Jakarta: Kencana.

Scunk, Dale H. (2012). Learning Teories (Teori-teori pembelajaran: perspektif pembndidikan). Yogyakarta: Pustaka Pelajar.

Slameto. (2003). Belajar dan Faktor-Faktor Yang Mempengaruhinya. Jakarta: Rineka Cipta.

Smaldino, S.E., Lowther, D.L., \& Russel, J.D. (2011). Instructional Technology and Media for Learning (9th ed.). Diterjemahkan oleh Kencana Prenada Media Group.

Suharnianti. (20110). Perancangan Company Profile Interkatif Sebagai Media Informasi Dan Promosi Pada CV. GLobal Multimedia.

Sudoyo, Peter. (1992). Azas-azas fisika jilid 3/Peter. Soedojo-Yogyakarta: Gadjah Mada Univercity Press.

Sutopo, Ariesto Hadi. (2002). Animasi Dengan Macromedia Flash Berikut ActionScript. Jakarta: Salemba Infotek.

Sudjana. (2009). Penilaian hasil proses belajar mengajar. Bandung. Remaja Rosdakarya.

Suherman, E. (2001). Evaluasi Proses dan Hasil Belajar Bahasa inggris. Dirjen Dikdasmen Depdikbud.

Suparno, P. (2001). Filsafat Konstruktivisme dalam Pendidikan. Yogyakarta: Kanisius. 
Suryosubroto, B. (2009). Proses belajar mengajar di sekolah. Jakarta: PT RINEKA CIPTA.

Suyanto, M. (2003). Multimedia Alat Untuk Meningkatkan Keunggulan Bersaing. Yogyakarta: Andi

Soedjadi, R. (2004). PMRI dan KBK dalam Era Otonomi Pendidikan. Bandung

Soedjadi. (2001). Pendidikan, penalaran, kontruktivisme, kreativitas sajian dalam pembelajaran Bahasa inggris. PPS IKIP Surabaya.

Tim MKPBM. (2001).Strategi Pembelajaran matematika Kontemporer, Bandung: Penerbit UPI.

Tim Penyusun (Dessy, Ika, Yusti, Ulan). (2012). Inovasi Tanpa Batas Bahasa Inggris SMA/MA Kelas X, XI, XII. Yogyakarta: Kendi Mas Media.

Vaugan, Tay. (2004). Multimedia Making It Work Edisi Keenam. Yogyakarta: Andi.

Vos, Stormorken A, Menko F H, Nagengast F M, (1999). MSH2 mutation carriers are at higher risk of cancer than MLHI mutation carriers: a study of hereditary nonpolyposis colorectal cancer families. J Clin Oncol.

Wedjo, Silvester Sila. (2006). Teknologi Informasi dan Komunikasi Untuk SMA dan MA. Jakarta: Grasindo.

Wahana Komputer. (2009). Pengembangan Web Kreatif Dengan Adobe Dream Weaver CS4. Jakarta: Salemba.

Warsita, B. (2008). Teknologi Pembelajaran, Landasan dan Aplikasinya. Jakarta: Rineka Cipta.

Wena, Made. (2009). Strategi Pembelajaran Inovatif kontemporer-suatu tinjauan konseptual Operational. Jakarta: PT. Bumi Aksara. 